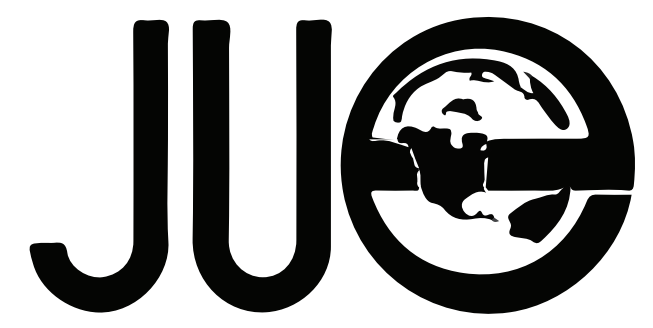

The Journal for Undergraduate Ethnography

Volume 6 | Issue 2

ISSN 2369-8721

\title{
A Look at Lived Hierophany: Eroticism, Ethics and the Eucharist in a Greek Orthodox Hermitage
}

\section{Lucas Kane}

Lewis \& Clark College, lucaskane@lclark.edu

\section{ABSTRACT}

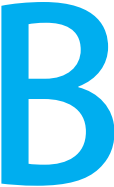

ased on two months of research in a small monastery in Northern Greece, this paper explores the

conceptions, definitions and practices of Orthodox Christianity as understood by Father Makarios, the monastery's abbot. I describe his emphasis on the sensuality of Christian practice, first examining how his definition of Christianity revolves around an individual's pursuit of Christ, a pursuit which rests upon both Christ's love for humanity (demonstrated in the Crucifixion) and humanity's seeking love for Christ. I go on to analyze this sensuality of monastic daily life, arguing that Makarios' definition of Christianity informs the ideal of his own pursuit of God (in which he seeks union with Christ). This definition and pursuit are mirrored in two daily examples: the consumption of the Eucharist, and Makarios' relationship with his disciple. I contend that in this monastery, sensuality is the medium and technique through which Christ is sought and the ineffable is made tangible in the everyday practices of the monks. Sensuality becomes a lived hierophany - a manifestation of the sacred.

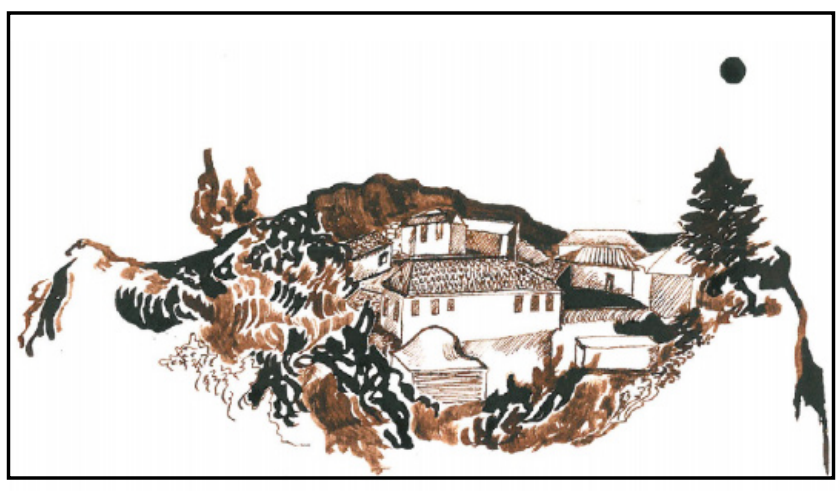

Figure 1, The Field Site: the hermitage of Marouda from a distance, Lilly Kizer-Taylor, ink on paper, 2015. 
Christianity is the opposite of religion. In the various religions people offer sacrifices to a god. In Christianity the exact opposite happens: God offers a sacrifice to the people, even His Son. God the Father offers His Son as a sacrifice to people to show them that He truly loves them, in order to reconcile them with Himself. The Apostle Paul says this in a wonderful way: "We are therefore Christ's ambassadors, as though God were making His appeal through us. We implore you on Christ's behalf: Be reconciled to God" (2 Cor. 5:20). What religion can present something like this? This is completely contrary to every religion. God is appealing to us to be reconciled with Him. All this is like an erotic story. Christ comes to earth, He tells everyone "I love you", humanity is indifferent, and Christ in order to "prove" His great love for man...commits suicide! Saint Nicholas Cabasilas likens Christ to a manic lover Who in the end, to prove His erotic love sacrifices His life. This is Christianity. It is something completely different from religion, it is not legalism. True Christianity is a true and lasting revolution, not a religion. The objectives of the revolution of Christianity are so wide, so great, with the result that this revolution will end only with the Second Coming. Whoever views Christianity as something static, as something that lacks movement, does not understand anything.

- Father Makarios, lecture excerpt ${ }^{1}$

To be sensual, I think, is to respect and rejoice in the force of life, of life itself, and to be present in all that one does, from the effort of loving to the breaking of bread.

James Baldwin, the Fire Next Time
Father Makarios, brushing a fish bone from his beard, leans a little closer to me. "Lucas," now putting his hand on my shoulder, "try to have a wish to eat your God." Pausing for a moment as if reading the reaction on my face and anticipating my next question, he continues, "Don't think about this as a theologian. Don't try to analyze it. Just try to grow this wish. My good boy, this is my wish for you." He then expressed, as he commonly did in moments of joy, company, prayer, wine, "I am so happy. Ah, I feel so close to you. Doxa tu Theo. Glory to God." And after making a gesture toward his heart- his hands spreading, from his chest, out and up- he raised his glass of wine to toast to the other ten men who gathered around this table for our post-liturgical Sunday feast.

This article is an attempt to give context to this wish, placing Makarios' advice in relation to the tables, Fathers, pilgrims, habits, liturgies, churches, and prayers that I experienced during my stay in and around Gerunda (elder) Makarios' killey (a small monastery) of Marouda on the famed peninsula of Mount Athos. And yet in doing so, I am doing exactly what he suggested I do not do-analyzing this wish as a theologian might (or, in this case, as an anthropologist). This duality composes the underlying questions of the following paper: one, seeking to make sense of Father Makarios' wish in relation to the everyday life, the rhythms and the rituals of the killey Marouda, and two, recognizing that such a project involves opposing the central logic of its inspiring question. In navigating this opposition, I attempt to enter and make sense of the life world of Marouda, examining its liturgies and social relationships, while also acknowledging that to enter such a lifeworld requires attending to an internal component, a pursuit, $a$ wish, and a presence of the divine, which are largely unknowable for the unbelieving anthropologist and often indescribable for those who live to seek them. 
I frame my exploration around the interplay between the material manifestations of that which is immaterial. I look to how God is eaten, how icons open up a potential divine relationship, and how an erotic love for God manifests in the subject formation of elder-disciple relationships, all in order to better understand the central feature of monastic life for the residents of Marouda and Father Makarios' definition of Christianity: the internal pursuit of and relationship with God.

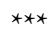

This study might be considered an exploration of lived religion, its everyday manifestations and practices - attending to the vernacular and subjective expressions of larger canonical, textual, and formalized religions. The introduction of an anthology on this subject, Vernacular Religion and Everyday Life begins by examining how religion as a term, as well as the methods used to study the term's contents, have prioritized both written forms and formalized liturgical rituals (“'Bowman et al. 2012, 5). Their project, however, is to emphasize the various individual and specific expressions of belief - 'articulated belief' as opposed to 'belief system' - thus working against the prioritized view of unified religion and the historical (and Christian) roots of this notion (Talal 1993; Bowman et al. 2012, 6). In large part, I try to do the same thing, focusing on how these articulations manifest in the daily life of Marouda and its inhabitants.

Yet belief is a difficult thing to define and a difficult thing to study. Bowman and colleagues argue that "although expressions of belief can be observed and studied, there is still something mysterious and elusive about them, as they tend to conceal more than they reveal. Beliefs have a great potential to be transformed into long narratives or elaborate rituals, although in daily life they seldom become anything bigger than short statements, expressions of modality or religious acts" (Bowman et al. 2012, 10). We might return, as we will continue to do, to Gerunda (elder) Makarios' simple comment to me. Try to grow a wish to eat your God. Such statements of advice and expressions of belief were mirrored again and again as people-monks and visitorsspoke about the Eucharist as literally God, the many miracles of Mount Athos, and the descriptions of the infinite life soon to come.

As with the above statements, and as with my entire research project, it often seemed that these articulations were simple, short, literal, and even habitual in a way that led less to my own clarified understanding and more to obfuscation. As in Makarios' advice that began this paper, our conversations usually consisted in simple declarations of truth, advice, wishes, and emotions in which follow-up questions were not always possible, and if so, were rarely fruitful. I often felt that such statements and practices left no room for my field notes and me. It seemed I was unable to move past what these expressions were in their external form in order to make analytical sense of what was being said or done. In fact, the initial articulation of my research question was a result of this naive frustration: where is this religion taking place? Even though it seemed all around me, it felt like I was searching among these moments of literal and commonplace articulations for something that was impossibly abstract. I shifted questions: how, in this particular killey, does belief manifest itself? But this led to a potential problem with the assumptions underlying a study of belief.

Anthropologist Webb Keane (2008), in addition to many others, has focused on an overarching conflation of religion with belief, suggesting that this focus on belief itself has been limiting to an anthropology of religion. Keane is mainly concerned with the assumption that a search for belief posits that practices, prayers, and the materials of religion are evidence for something else- namely an underlying belief. This is exactly what my own initial difficulties mirrored: the deceptively simple articulation of belief is only deceptively simple when I am searching for a presumed presence of something that exists behind these articulations. 
Keane asks us whether, rather than relying on an assumption of representation, we might "benefit from an approach to materiality that does not always expect it to provide evidence of something hidden, such as belief" (2008, S110). In other words, it might be productive to view these moments-be they Makarios' wish or the quick gesture of a cross over a yawn - as whole unto themselves, not doorways to something internal that the anthropologist may or may not enter. And in this way we reach again to Makarios' own wish for me: try to grow a wish to eat your God and do not get caught up in making analytical, academic sense of what this means.

But, taking a closer at the epigraph that began this paper, Makarios did not refer to himself as religious. For him religion signified 'ideology' and 'morality' in a depersonalized sense that revolved more around subservience to rules than devotion to God. "Never be religious," he told me during my first week there. "Don't get stuck in ideology. Just try, if you have the wish, to give your life up to God." Religion seemed to be a superficial outerform that coated the real purpose of his monastic life which is not, as he says, legalism. Christianity, by his terms, is a revolution of erotic sacrifice, of manic love, of continual movement. As defined by Makarios, it is the process by which the individual seeks through humble and devoted love to unify themselves with the lover they seek, as God Himself sought to do so through His erotic sacrifice aimed at the unification of humanity with Him.

Both religion and belief seem like incorrect formulations, based upon the above reasons. But understanding the lifeworld of Marouda requires both an attention to the external materialization of liturgy and daily practice, and an acknowledgement of a potential internal component to these things, which seem to, by Makarios terms, defy intellectual analysis . So, in the lifeworld of Marouda, intentions revolve around the project of giving one's heart up to God. Material forms and physical or verbal expressions have the potential to correspond to this project and to be understood within its context. In other words, by focusing on the relationship with the divine. Keane undertakes a similar project through his concept of ethical saturation, which also offers up a potential solution to the conflation of the terms 'religion' and 'belief' (Keane 2014).

In looking at the dynamics of icon veneration, Keane posits that a view of icons as miraculous and affecting materials creates a world that is ethically saturated. Ethics in this case refers to an individual's ability "to evaluate acts as good or evil, people as virtuous or vicious, lives as worthy or worthless, and to their awareness of being themselves evaluated in turn. Typically these evaluations arise in interactions with other people, but they may involve any entity at all (such as divine beings) whose actions can be judged in these terms and so can be held responsible for purposeful harm or benefit" (2014, S316). As agentive materials and unions of the material and spiritual, icons offer a particularly revealing instance of semiotic ideology and ethical affordances. Icons "manifest the active stance of divinity toward each ordinary person. By treating relics or icons as having agency in themselves, [individuals] are insisting on the saturation of life with ethical implications. That is, the possibility of social interaction with divine actors is everywhere, and social interaction can always be construed as having ethical import" (Keane 2014, S319). Icons blend the material and spiritual, providing a potential site for interacting with the divine, and thereby requiring that devotees are ethically prepared for this potential interaction. In other words, depending upon the ethics of the individual, such materials may be able to support the individual pursuit of union with God.

This leads us to the central question of this paper. How is the immaterial quality of Orthodox 'religion' (the pursuit of the divine, or giving one's heart up to God) located within the material, placebased, and specific lifeworld of this hermitage? More simply, how is God sought in Marouda? Implicit in the formulation of the immaterial and material is also a question of the relationship between the external form of religion and the possible internal form of belief, of public liturgy and private prayer. In 
answering these questions I hope to help the reader enter into the lifeworld of Marouda, suggesting that the quick gesture of a cross above a bowl of soup, a prayer read before baking bread, an utterance of glory to God after a joke, an icon above the doorway, the quiet blessing of a priest, a kiss of the hand, position and compose the interplay of material and immaterial, and the erotic and the ethical. Simply then, I am seeking to understand how the sacred manifests itself in everyday life, or how hierophany is lived, relying on Eliade's definition of hierophanies as both manifestations of and participants in the divine (Eliade 1952). In section one, I take a deeper look at ethical saturation in relation to the ritual of divine liturgy which began our everyday, expanding Keane's term past icons to suggest that life at Marouda is saturated with ethical implications. After this, I explore the meaning behind Makarios' definition of Christianity as opposed to religion, focusing on his emphasis of the erotic, specifically examining how God's love for humanity is mirrored in the elder-disciple dynamic of Makarios and Pavlos. For the purposes of this paper, I am relying on Makarios' utilization and definition of the erotic: namely, the devotional love for the divine through which divine union is sought, manifesting in an omnipresent sensuality.

\section{On Methods: Form, Context, and Reconciliation}

My access to Mount Athos and Marouda was provided through a family friend who became close to Makarios in the early 90s. Through this connection I was able to attain the required entry visa to the Autonomous Monastic State of the Holy Mountain, as it is formally called. ${ }^{2}$ My arrival to and my initial few days at Marouda were mainly guided by the uncertainty of my position and the insecurity in being able to conduct fieldwork.

On the evening of my first day Makarios, in front of the many other visitors, massaged my feet with oil in a sort of modern adaptation of the ancient monastic custom of anointing a visitor's feet with oil. This action was accompanied with laughter from the other visitors and Makarios' expressions of "I love how bright your eyes are. I have a good feeling about you!" and asking of the larger group “doesn't he have bright eyes?” Makarios' physical and loving reception, taking various forms throughout my stay, has largely guided my prioritization of the material, the sensual, and the erotic qualities of life at Marouda.

A few days later, when I spoke to Makarios about my studies as an anthropology student and my interest in writing about Marouda, he listened, nodded and then proceeded to comment again on the brightness of my eyes. While after a few weeks Makarios allowed for me to proceed with my research, he always seems to treat my role as researcher as an aside to my being there, and my research role did not seem to receive focus or even raise concern. Prior to interviews, I always asked for consent and after specific, important ethnographic moments, I always confirmed with the relevant informants.

Although by his own admission I became close to Makarios, our relationship never involved detailed verbal communication and conversation. While Makarios would often spend hours speaking with other visitors, in regards to our relationship, Makarios felt that words were not necessary for our communication. He would often say that he felt like we understood one another perfectly without words. In fact, I often thought it was because he was constantly asked questions by other visitors that he took some solace in our relationship in which words and conversation were of little importance, to Makarios at least. While I tried to appreciate the sentiment, it made fieldwork and interviews quite difficult. For instance, I once asked him why he decided to become a monk. He took a while to respond and then began to chuckle: "so I wouldn't have children like you asking me questions like that!" Makarios never spoke to me in the manner in which I have quoted him in the epigraph that begins this paper, an excerpt taken from a lecture at which I was not present. This is important to note, because when he did speak to me, it was in simple expression and the brief moments of advice that I have quoted above. To 
me, Makarios continually emphasized the physicality, simplicity, emotionality of both our relationship and the larger practice of seeking God. Again, it is for these reasons that I prioritize such themes.

In other words, such qualities of participation, acceptance, and intimacy born of necessary method have guided the formation of my research questions and understanding of the workings of the community. In the ways that I am able, I try to follow Makarios as both ethnographic and theoretical guide, at times mirroring his mode of thought and description within my own writing, as best I am able. This is similar to Susan Harding's research with Evangelical Christians. She writes about how reverends took rhetorical control of interviews, shifting them into opportunities to 'witness' and convert (1987, 170). In my case, my academic questions were not met with verbal attempts at 'witnessing', but with physical responses - a hug, a kiss of the hand, a pat on the head, a flare of the eyes. Similarly, Harding privileges the rhetorical, mimicking the style of her informants within her own writing:

The membrane between disbelief and belief is much thinner than we think. All I had to do was to listen to my witness and to struggle to understand him. Just doing so did not make me a fundamental Baptist bornagain believer, but it drew me across that membrane in tiny ways so that I began to acquire the knowledge and vision and sensibilities, to share the experience, of a believer... this space between belief and disbelief, or rather the paradoxical space of overlap, is also the space of ethnography. We must enter it to do our work (Harding 1987, 178).
Following Harding, I contend that the space between belief and disbelief is thinner than we think. While the process of giving one's heart up to God is, as Makarios suggests, a complex and laborious process, it is also unclear and indistinct, bleeding into the way he interacted with me and others. Just as speech ushered in a session of 'witnessing,' Makarios' touch, anointings, comments and wishes, ushered in an erotic relationship, blending the ethics of social relationships with the ethics of pursuing the divine. In attempting to understand this, I also try to do my work from within the thin, porous membrane that separates between belief and disbelief. At this point, it is important to state that I am not an Orthodox Christian, nor am I affiliated with any denomination. This said, I do attempt to blend the so-called etic and emic sections of analysis, allowing for the capitalization of God, the absolutes, and the faiths of my informants to spill out through the style, voice, and analysis of this paper. This mildly 'unorthodox' method of anthropological voice is part of my attempt to write from 'the space of ethnography, hopefully allowing the eros, the sensuality, the faith, and the seeking of my informants to breathe within these pages of academic analysis, which, again, informants contend is counter to understanding the truths of their monastic practice.

Lastly, while Makarios, Pavlos, and many visitors spoke English with near fluency, Church services and the majority of conversations in Marouda happened in Greek (with occasional ones in Russian). My basic Greek in no way provided me with the tools to understand the post-liturgical discussions over coffee or the scriptures read at meal times, which unfortunately excluded me from some of the richest ethnographic material. Through filming and later translating the footage with the help of a long-term visitor, I was able to document some of these conversations which now compose a large part of my ethnographic material. 
Makarios spent seventeen years in a cenobitic monastery. Makarios and Pavlos are currently the only permanent monks at Marodua, which is classified as an idiorrhythmic killey, a cloister in which monks follow their own rhythms and wishes, as opposed to the disciplined schedule of a large monastery. The anthropological scholarship on Mount Athos predominantly focuses on its cenobitic monasteries. While that means my study is unique, it is also of an extremely specific micro-culture that does not necessarily reflect the larger peninsula, let alone Orthodoxy in general. (This is mirrored in the fact that Makarios and Marouda were continually heralded by visitors as unique manifestations, and the authentic form of Orthodoxy.) Thus my claims and findings here are limited to the context in which I found them. Hopefully, I am able to remedy this through grounding the liturgies and physical place within their historical contexts, and through connections to scholarship on the same topics.

\section{Divine Liturgy}

At 5:30 I can hear the footsteps of Makarios coming down the hall. Since my third day here, Makarios has taken to waking me up before the 6:00 AM service begins. Opening the door, he enters with a Kalimera paidimoo (good morning my child) before he touches my forehead with a smile. He asks, my boy, did you sleep well? And receives my answer with some excitement before asking me, as he continued to do for the duration of my stay, bells? Bells? Will you ring the bells? He says good, good, when I respond-as I always do- in the affirmative. He leaves quickly, lingering in the hallway to knock on the doors of other visitors.

At 5:50 I ring the bells. Soon after my acceptance into the community here, another visitor, Seraphim, under direction from Makarios, passed on this bell duty to me, speaking out the rhythm before doing so: toná dam, toná dam, toná dama dama dam. Dam. Dam. Dam. ${ }^{3}$ It's an ancient monastic rhythm played upon the cast iron bells or on the simple wooden semantron, meant to signal the joyful celebration of the coming of divine liturgy. The sounds, toná dam, Makarios says, reminds us of Adam, the wood of the semantron reminds us of Noah and his ark of salvation, and the bells and their ringing symbolize the sound of the Apostles. "Everything has its meaning, it's not just done," he tells me.

So at 5:50, the bells ring. Three or four visitors make their way to the church. They pause in the entrance to light a candle. They bend before and kiss the icon of Panagea (the Virgin Mary), before joining the one or two early risers who already stand in the dimly lit church. At six o'clock Father Pavlos, Makarios' disciple of seventeen years and the only other permanent resident of Marouda, will begin his soft chanting as he reads from the pulpit the morning prayers, thanking God for the coming day, praising Him to permit this service, and oh Lord now having arisen from sleep, we fall down before Thee, O Blessed One, and sing to Thee, O Mighty One... Glory to the Father, and to the Son, and to the Holy Spirit. ${ }^{4}$

At 6:30 the Divine Liturgy itself begins, and the small church and its pews are now occupied with all those who will attend. Elder Makarios and his disciple Pavlos remain in the cloistered room for priests only, joined to the main room by two curtain-covered doorways that punctuate the carved and slotted wooden wall. There, white-robed, they will serve the liturgy, taking the small round of wheat bread and ushering in the body of their Lord in its stead. In the main room, the rest of us stand when we are supposed to stand, and sit when we are permitted. Some nod with closed eyes-perhaps in deep prayer or perhaps returning to the sleep they recently left- others bow over their prayer ropes (kimbuskinis), while those who were asked stand before the pulpit chant and read from the liturgical script, alternating between each other, Makarios, and Pavlos. Now, the doorway that separates the preparation of the Mystery with the faithful attendees opens and Makarios enters, his gold-cuffed hands swinging the burning incense, letting us know-letting us sense- that the divine is now present. He swings the thurible towards the icon of 
Christ, he swings it toward John the Baptist, before incensing the congregation, moving counterclockwise around the church as our bowing heads precede his coming, and crosses pattern devotion on chests and torsos.

Now, Makarios and Pavlos enter through the side door of their barrier, holding before the congregation the covered chalice and basket of now divine Blood and Body. We bow again before the second most holy moment of the service. As the chanters continue at the pulpit in the fore, the prayers of Makarios and Pavlos pause as they themselves give one another communion behind the closed curtain door. As they commune we continue to prepare, as one by one the congregation prostrates before each icon, kissing the relics of holy bones, and painting their bodies with the three fingered movement of the holy trinity. With the last icon kissed, the doors open, and those baptized Orthodox proceed to the cup that contains their God. Open-eyed and wide-mouthed they approach Makarios, as Pavlos, by his side, holds the candle and chants: Loving Master, Lord Jesus Christ, my God, let not these holy Gifts be to my condemnation because of my unworthiness, but for the cleansing and sanctification of soul and body and the pledge of the future life and kingdom. And With the fear of God, with faith and with love, draw near. Christ is in our midst! Makarios, dipping silver spoon into golden cup, feeds each entreating member.

Wiping mouths, crossing, bowing: the rest of the bread from which the Body has come is passed around. No longer crust, it is now the Mother of God, Panagea, and is given freely to all, baptized or not, in order that all may taste Orthodoxy and lift themselves towards the heavens. As the sun approaches its 8:30 height, we cross, leave, and take our Greek coffee in the courtyard. Let us depart in peace. Let us pray to the Lord. Lord, have mercy. Lord, have mercy. Lord, have mercy. Holy Father, give the blessing!

I begin here because all our days did. Repeated every day (unusually, given that most monasteries serve liturgy two to four times a week), liturgy temporally framed life at Marouda as its main calendrical referent: days began here and ended in evening vespers which served to prepare for the following morning's liturgy. But more than just dividing the day's time, liturgy also seemed to provide a coherence, a temporal union, connecting the small Church and its inhabitants to the long and valorized continuance of Christian prayer and Orthodox liturgy. Perhaps this is a simple point, a recollection of the the distinct space of the sacred and its function of returning its occupants to the primordial time, a time out of time. However, it helps us in our project by highlighting, as Eliade tells us, that the temporal and the sacred within Christianity is historically concrete and actualizable: "Christianity affirms the historicity of the person of Christ. The Christian liturgy unfolds in a historical time sanctified by the incarnation of the Son of God. The sacred time periodically reactualized in pre-Christian religions is a mythical time, that is, a primordial time, not to be found in the historical past" (Eliade 1952, 72). But in the case of Christianity, specifically with the material incarnation of its God, its sanctity is historical, concrete, and material (1952:111.

As a recollection of the historical event of the crucifixion and resurrection, the Divine Liturgy reenacts "the bloodless sacrifice wherein the sacrifice of Christ on the cross is repeated in mystical fashion" (Benz 1963, 34). It is the celebration of Christ's historical narrative, and as one theologian writes, "the entire complex of mysteries of the Orthodox Church revolves around the prime mystery [of Divine Liturgy]: the death and resurrection of Christ" (McGuckin 2008, 288). Participants in anthropologist Sonja Luehrmann's fieldwork described the liturgy of Orthodoxy as distinct from other denominations, in that other denominations merely “'remembered' [biblical events] whereas in Orthodoxy they actually 'happen' or 'unfold”' (Keane 2014, S316). Orthodoxy is "conceived to be a living tradition (paradosis), a continuous hermeneutic interaction in which individuals are guided by the Holy Spirit toward consistent interpretation of both Scripture and the existing body of tradition" (Hann and Goltz 2010, 2). As one 
Father said, quoted in a 60 Minutes television program about Athos: "You have to understand, the words that we're saying in today's liturgy are the same words that Christ was saying, are the same words that saints from the first century, the second century, the third century, the fourth century [were saying]" (60 Minutes).

Paul Connerton $(1989,5)$ makes a useful distinction between what he calls inscribing practices (long-term storage, written text) and incorporating practice (embodiment, physical habit). As Mitchell, who uses Connerton's concept in relation to Catholic Liturgy, puts it, incorporation "involves the human body internalizing knowledge so that social memory is 'sedimented in the body"' (Mitchell 1997, 89). In Connerton's understanding, commemorative ceremonies are rituals of re-presentations and re-enactments of the past: "our bodies, which in commemorations stylistically re-enact an image of the past, keep the past also in an entirely effective form in their continuing ability to perform certain skilled actions" $(1989,72)$. In applying this to the social etiquette of 19th century European aristocrats, Connerton says that social memory requires a "presence of living models, the presence, that is, of men and women actually sitting 'correctly', [which] is essential to the communication in question" $(1989,73)$. The moral order the proper behavior of the elite, and the distinction of such behavior from lower classes, are all contained and maintained in the body, its postures and habits. In our case, the small church in Marouda exceeds its 30 -foot by 20 -foot dimensions because it is enmeshed in extended historical and social networks of Christian lineage which are inhabited and re-inhabited by the physical gestures of the rituals' inhabitants. The body becomes a site of interplay between historical lineage and social memory that is at once personal, impersonal, collective and individual. This interplay of collective and personal memory is similar to Rappaport's idea that in practicing the liturgy, a person is not simply transmitting the message of the liturgy but rather "is participating in-that is, becoming part of - the order to which his own body and breath give life" (Rappaport 1999, 118). Looking at this becoming part of more deeply:
To say that performers participate in or become parts of the orders they are realizing is to say that transmitter-receivers become fused with the messages they are transmitting and receiving. In conforming to the orders that their performances bring into being, and that come alive in their performance, performers become indistinguishable from those orders, parts of them, for the time being. (Rappaport 1999, 119, emphasis removed).

The conjunction of collective and personal, the temporal and outof-time, has the corporeal body as its working site. Participants blend with the orders, morals, histories of the ritual at hand, a melding of identity, or memory, of the body. In Makarios' understanding, when he serves liturgy, his hands became melded with God's own, a channeling of divine presence that changes the bread to the Body, connecting him to the long tradition of the Orthodox priesthood and the thousand liturgies which are served on Athos, at the same time of day, every day.

Let's return to what Makarios told me as we sat beneath the bells: we have symbols for everything. Nothing just is. As you enter the church you bow before the Virgin Mary, Christ, John the Baptist, Saint Seraphim, Saint John of Damascus. You kiss their feet, you kiss their hands, and you kiss the small relic of bone from a previous Father of Marouda. You inscribe upon your body the sign of the cross, you articulate the correspondence of the Holy Trinity within your own body, your three fingers composing the Mystery of omnipresence: the Father, the Son, and the Holy Spirit. The symbol of the cross is present in the multitudes of carvings and crucifixes (on pews, walls, necks, wrists), painted around the colorful and layered interior of the church. For Makarios the cross is also present in the way the pews position their inhabitant to stand, physically forming the cross with the body: 
You see, we don't have seats. We have pews where you can stand and have your hands, like that [resting at your sides]. This represents in a way, the cross. From the times of Moses...there was a quarrel among the Jews and the Amalekites. As far as [Moses'] hands were in the sign of the cross, the Jews were winning [against the Amalekites]. And when [Moses'] arms collapsed, Aaron and somebody else were holding them [up in order to maintain the sign of the cross], and the Jews [continued to win]. That's why when we stay in this kind of pews, our body makes the sign of the cross. And it helps. You don't just sit down and sleep. You are standing, like that, not stiff, but the pews help you to stand, you have your arms here. And you can more easily pray and concentrate. Because if you sit, after a while you [go] to sleep. ${ }^{5}$

Here, Makarios directs our attention to the way in which the position of the body corresponds to the central symbol of the cross. The sign of the cross, physically manifesting in the position of the body, serves to ground the participant both within the lineage of the symbol, its historical and religious meanings, and within the present moment, so as to maintain concentration and attention rather than losing oneself in sleep. It helps. The ritual, which extends into daily life beyond the service, focuses attention on the relation to and pursuit of the divine. Through icons, incense, candles, chanting and the actual text of liturgy, the participant is potentially guided, centered and recentered around the preparation for consuming the divine.

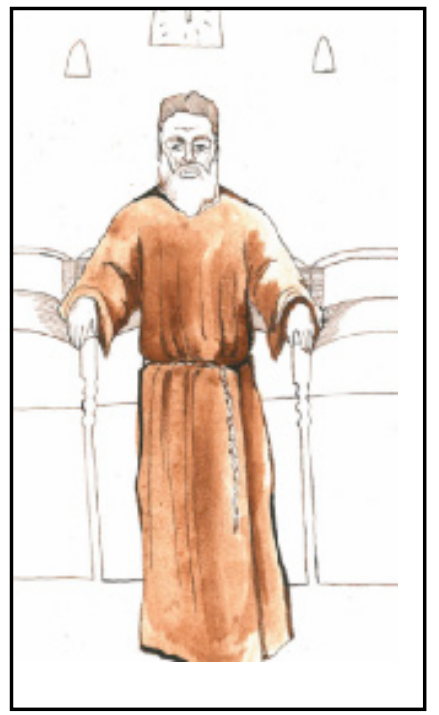

Figure 2, Makarios in the pews. Lilly Kizer-Taylor, ink on paper, 2015]

Makarios continued to say that "the body is present everywhere, and we don't cut it into two or three parts. The human being is one. Mind, soul, body. We don't cut it in pieces. And you pray with your body, you pray with your mind, you pray with you soul. The whole thing is praying. You have the singing, you have to stand in the pews there in the church. You smell the incense, you see the lights, you see the icons, everything works. All the senses." The use of the senses, like the embodiment of the cross, serves a practical and tangible process of developing and maintaining a working presence that allows for personal prayer in and through the union of the body. The burning incense, swinging in the silver thurible (which Makarios says corresponds to the moment in divine liturgy when the divine becomes present) serves to attune one's sense of smell to the service at hand. Icons and the burning candles engage the sight and touch. Here the senses and the corporeal body become both the location and the tools through which the individual is connected to the communal, the historical and the divine, again re-circling one's focus towards the divine and individual prayer. 
In Makarios' terms, the senses and the body are preparatory tools that ground the individual in the present. And through such a presence, the individual is able to potentially better extend the ethics required for meeting the icon, or the Eucharist. The cross hanging round the neck, also manifesting in the position of the body, the hundreds of icons and engravings-the story of Isaac, Noah's Ark, the founders of Hilandar monastery- have the potential to ground participants within the present ritual, facilitating prayer, the means of an individual's communication with God. As theologian Coniaris says, "we must realize that Christianity is a personal encounter with the living Christ and not merely with the symbols of the Church. Symbols are a means toward this goal ... The Bible and the Church have shaped symbols for us and then they in turn shape us" (Coniaris 1985, 10-11, emphasis added). In turn, we must keep in mind what these symbols, histories, commemorations revolve around: "to the mind of the Orthodox believer, the real significance of the Eucharist lies not much in the repetition of the sacrifice ... but in the encounter with the living, resurrected Lord” (Benz 1963, 38).

One morning while working in the garden after liturgy, Makarios cut a piece of cucumber with his knife. Beckoning me to him, he fed it to me, informally mimicking the act of communion. As I came forward to receive his gift, he said that "eating, consuming, is the most loving and erotic act man can do." Returning to Makarios' understanding of Christianity, 'true Christianity' is manic love, and the erotic sacrifice of God to an estranged humanity. As the most erotic act, eating the Eucharist is the moment when the individual is physically united with the living God. Through the Eucharist, then, the sacrifice is repeated, and the individual consumes the erotic offering, physically ingesting it in an undoing of divine estrangement.
But it is subtle, said many monks and visitors I spoke to. One visitor said, it is like spiritual food, and its divinatory strength builds over time in a quiet growth of connection. "We feel" said Dimitrius, a long-term visitor, "God himself gave us the best way to connect with him. It is like a mother's milk." "For me it is a moment of love. I just feel joy," said Seraphim. "It is my whole purpose when I stay in Marouda," said Father Rafael, a visiting monk. Continuing, he clarified that "we believe it is the literal consumption of God." "It is not a metaphor," said another visitor.

As the center of liturgy, all instances of embodied symbol, of embodied tradition, lead to the moment of consuming the Eucharist. Such consumption is the also the central erotic act in Marouda, again life here revolves around divine liturgy. And, again, the purpose of liturgy is the consumption of the Eucharist; it is the physical union of congregant to God. In the eucharistic case then, we again have a window into this relationship of how the erotic pursuit of God, as well as God's erotic love for humanity, are grounded within the material day to day life, and how the erotic is the process and the tool through which this union in navigated. Further, as the voices above suggest, the Eucharist, at the point of consumption, is God's Blood and Body. It is not symbolic of anything. It is not a metaphor for God. While many anthropologists contend that everything is symbolic, in the case of the eucharist, understanding its sanctity, its efficacy, and its importance in the lives of my informants, requires recognizing its a-symbolic quality. The eucharist, perhaps the most emphasized example of hierophany, is not only an example of how God is given form, but also how such form is ingested in an erotic and intimate act. Further, the ethics that guide the behavior of the participants in the ritual lead to this moment of interaction. Makarios' ethics of presence of prayer lead to his preparation for receiving the Eucharist. The sensual practice of his eroticism is the medium through which he seeks to 'give his heart to God'. I will explore the role of eros in greater depth in the following section on Makarios' understanding of social interactions, and specifically his relationship to his disciple Pavlos. 


\section{Elder and Disciple}

Makarios and Pavlos share a separate house in the killey. While they once lived in the main house with all their guests, six years ago they were getting too many visitors to comfortably house them and felt that they needed a separate place for rest and prayer. In their house, they share all the rooms. They sleep in adjoining beds which meet at the head, so the tops of their heads meet when they rest. As Makarios says, they share all they have, money, robes, everything (except their hats, because, Makarios laughs, Pavlos' head is too small). In the mornings before liturgy, they rise together, and sitting opposite one another, recite the Jesus prayer together-Lord Jesus Christ, Son of God, have mercy on me, a sinner. They serve liturgy together, giving one another communion behind the slotted wall of the church. As Pavlos described it, "it's not just that he's my older brother. He is my father, my uncle, my mother, except Panagea (the Mother of God) of course. My friend. [He is] my best friend...it is all together in one thing." He also emphasized that it was also like they were husband and husband, sharing in their union with Panagea and Christ. Many times, usually when Makarios had a glass of wine (which Pavlos poured for him), Makarios would tell me, "yes, we have struggled for seventeen years. But oh Lucas, now it is so nice. Everyday Pavlos and I get closer and closer. Of course we fight, but every day it is better," and, pausing as he looked out from the porch, "He is my greatest gift in life. Oh, I thank him. Doxa tou Theou." Glory to God.

It might be helpful to look at spiritual discipleship as a skill to be learned through apprenticeship. Taking a phenomenological approach, Gieser (2008) looks at how apprenticeship is a combination of embodied emotions and empathetic learning, and not simply a mode of skill transfer through mimicry. By treating bodies and emotions as 'in-the-world', relational and environmentally intertwined, Gieser argues that the apprentice seeks to enter the emotional and physical realm of their teacher, which means "entering the private perceptual world of the other and becoming thoroughly at home in it. It involves being sensitive ... to the changing felt meanings which flow in this other person ... [I]t means temporarily living in his/her life" (Gieser 2008, 308). In this ideal state "both teacher and learner try to synchronize their actions through an increase in intersubjective communication, continually fine-tuning their movements and checking their intentions. When we are usually with our body here we are with both our own and the other's body simultaneously. Two individual I's become one Us that is experienced as the center of subjective life" (Gieser 2008, 313).

Treating Makarios and Pavlos's relationship in this light, we see again a blending of individual identity, perceptions, bodies, sensitivities. Two individual I's become one Us. As a disciple, Pavlos seek to enter the world of Makarios. For this reason, we can also better understand why lineage is so important to the Athonite elder-disciple relations. Makarios sought to shed his individuality and inhabit the world of his elder, as his elder did before him, with the ultimate goal being that the individual personality and will is blended with that of God's own. With the divine as our organizing principle in this monastic community, human relationships are not viewed as distinct from divine relations, understanding, embodied slowly through master-disciple empathetic learning, these relationships are saturated with a divine ethics they lead us to the state of freedom which Makarios valued, and used to describe the feeling of interconnection with God.

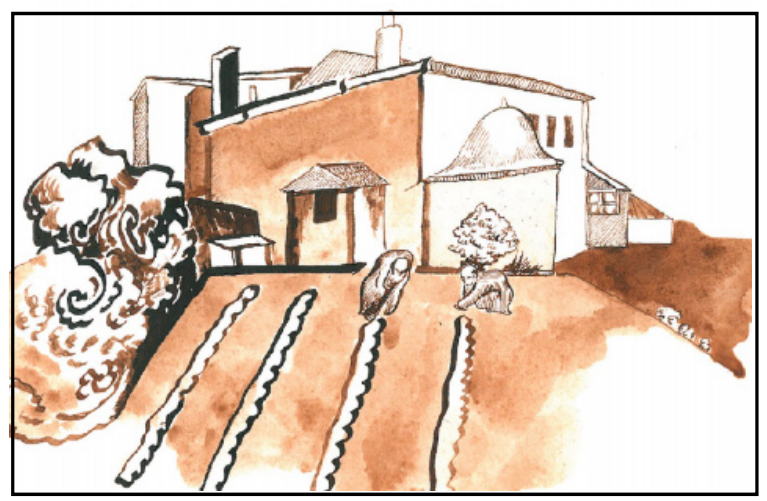

Figure 3, Makarios and Pavlos in the garden, Ink on paper. Lilly Kizer-Taylor, 2015. 
In explaining one of the ways this empathetic blending took place, Makarios said his initial hesitation and even dislike of Pavlos wore off as Pavlos became close to the visitors Makarios himself was closest too. They began to share similar feelings about others and thereby became closer themselves. Makarios seemed to value this quality of empathetic feeling as the greatest confirmation of his relationships. He would often check in to see how I related to certain people, gauging my interpretations in relation to his own, nodding joyfully if our feelings overlapped. In a similar sense, he once told me of a friend who came to Marouda in order to do some photography. Makarios described how his close friend described in detail how he took photos, cut the rolls film, made a darkroom and developed them; "it was so nice." Makarios' eyes now wide with excitement. "We were so close to one another, I felt as if I was doing it, [as] if I were a photographer." In the case of Pavlos and Makarios' closest friends, it seemed that he validated their closeness through these vicarious, empathetic moments, which led to the blending of identity, of sensation, of bodily experience. These little comments reveal the monastic process of empathetic blending. The empathetic melding of the two separate selves of Makarios and Pavlos comes close to the type of relationality that Foucault (1994) celebrated in his exploration of Socratic love and the reciprocity of erotic love, through which he relates ethics and freedom.

Foucault uses the Socratic dialogue of Alcibiades as a starting point. An aging youth whose suitors are disappearing, Alcibiades wishes to become a politician in order to have power over others: "He refused to let himself be dominated in youth, but now he wants to dominate others. This is the moment Socrates appears, and he succeeds where the others have failed: he will make Alcibiades submit, but in a different sense. They make a pact-Alcibiades will submit to his lover, Socrates, not in a physical but in a spiritual sense. The intersection of political ambition and philosophical love is the 'care of the self"' (Foucault 1994, 229). Foucault writes again, "You have to worry about your soul-that is the principle of caring of yourself. The care of the self is the care of the activity and not the care of the soul-as- substance" (Foucault 1994: 230-231). Leo Bersani’s essay (2008) on the power of love and evil examines this dialogue, via Foucault, looking at how this erotic form of the care of the self relies on a notion similar to our discussion of the empathetical apprenticeship (Bersani 2008; Foucault 1994, 229).

Bersani writes: "in the generous narcissism of the exchange between Socratic lovers, each partner demands of the other (as we see Socrates demanding of Alcibiades in the dialogue Alcibiades) that he reflect the lover's type of being, his universal singularity (and not his psychological particularities, his personal difference), by recognizing and cultivating that singularity as his own most pervasive, most pressing potentiality" (Bersani 2008, 84). The lover seeks to shape his lover into himself. This is not based in the individual narcissism of personality; instead, it is making "every possible effort to draw [the beloved boy] into being totally like themselves and the god to whom they are devoted." Thus, a lover is at the same time attempting to make the boy more like himself. The lover narcissistically loves the image of his own universal individuation that he implants in the boy he loves, but he is implanting more of what his beloved is, more of the type of being they already share. Far from suppressing the other, the Socratic lover's narcissism suppresses accidents of personality so that the loved may more adequately mirror the universal singularity mythified in the figure of the god they both served" (Bersani, 82).

The shared telos of God, this universal singularity, allows for this type of shaping eroticism to skillfully take place in the monastic relationship of elder-disciple. Makarios and Pavlos are involved in an erotic relationship_as Makarios was with his elder Ephraim, and as Ephraim was with his elder Saint Joseph the Hesychast - in which elder and disciple work in order to shape Pavlos into the ideal they both seek. This is not simply based upon personality or the likes and dislikes of Makarios; it is based upon the seeking of God and his perfection. Thus, the monk, as a lover of God, seeks to submit his will to that of God's own: "to live his life on earth in the spirit enjoined by Christ" (Sophrony 1977, 69). As Pavlos articulated nicely, "The point is to be with God. So for 
me, the way is living with Gerunda now, and to go [to heaven] together. This is [it] for me. This is my life. The purpose...That's why we pray to God to take us together when our time comes."

Looking back again to Makarios' definition of religion, it is erotic love that guides God's relationship to human, and in turn informs how humanity might love God; the "beloved becomes the lover as a result of being loved" (Das 2010, 397). The beloved conjoins with Christ through erotic love to Him. In the elder-disciple case, eroticism is an attempt for the lover to shape the beloved into himself, into the ideal, the God they both serve and seek. It is not based in personality, or narcissism, of the lover, but rather is based upon their shared telos, the achievement of paradise, the union with God. The eroticism of the elder-disciple relationship is paralleled in God's love of humanity. And like the ethics that guide the consumption of the Eucharist, here, eroticism is the medium through which the physical is connected to the immaterial; through eroticism and the ethical, the immaterial is brought into the physical materials of everyday life-be it the kiss of an icon, or the feeding of an anthropologist in the garden.

The sense-based prayer of the Liturgy and the consumption of the Eucharist, and the empathetic love of elder and disciple, are just two examples of how Makarios' understanding of Christianity (the individual seeking union with Christ) seemed to manifest in the day to day life of Marouda. Again, the individual's relationship to, their seeking of, God was the purpose of monastic life in Marouda. This paper has attempted to make sense of such an internal and unknowable pursuit, which, for my informants, defies intellectual reasoning. In turn, I have sought, first, to question the value and role of anthropological thought in making sense of lifeworlds that extend far past the confines of material, social relationships (which we as anthropologists often linger in) and stretch into the difficult realms of absolute truths and everlasting life; and second, to make sense, as best as I can, of how Makarios' definition of religion manifests in his, and his disciples, daily monastic practice. While I have by no means laid out such absolutes as 'true' or 'false,' I have allowed space for them to exist, thereby making room for the many dimensions of Makarios' erotic monasticism to come into play. In opening up my inquiry in this way, I have offered a deeper understanding of why the social relationship of elder-disciple, or the liturgy of the Eucharist, exists as it does in the killey of Marouda. 


\section{Acknowledgements}

My deepest gratitude belongs to Father Makarios for demonstrating, through daily action, the most open, kind, and receptive hospitality I have known. Such generosity was paralleled only by his disci-ple Pavlos. I must also thank my fellow visitors of Athos, specifically, Kyrios Biezanis, Tasos Ethymiu, and Demitrius Tzakis. Many thanks to Phil Metzadakis for his willingness to share his Athonite connections. And lastly to my many professors: Robert Goldman, Kabir Heimsath, Sepideh Bajracharya, and Jennifer Hubbert. This research project was made possible through a grant from the Student Association of Lewis and Clark. My gratitude also to the JUE. To watch a short documentary film made by the author during this fieldwork, visit https://vimeo.com/162285348.

All illustrations were drawn by Lilly Kizer-Taylor, based on photos taken by the author. Reproduced courtesy of the artist.

\section{References}

Baldwin, James. 1963. The Fire Next Time. New York: Vintage Books.

Benz, Ernst.1963. The Eastern Orthodox Church. New York: Doubleday.

Coniaris, Anthony. 1985. Sacred Symbols That Speak. Minneapolis: Light and Life Publishing Company.

Connerton, Paul. 1989. How Societies Remember. New York: Cambridge University Press.

Das, Veena. 2010 "Engaging the Life of the Other: Love and Everyday Life." In Ordinary Ethics, edited by Michael Lambeck, 376-400. New York: Fordham University Press.

Della Dora, Veronica. 2011. Imagining Mount Athos. Charlottesville; University of Virginia Press.

Eliade, Mircea. 1952. The Sacred and the Profane. Harvest Book. New York.

Foucault, Michel. 1994. Ethics: Subjectivity and Truth. New York: The New Press.

Geertz, Clifford. 1993. Religion as a Cultural System. In The interpretation of cultures: selected essays,

Geertz, Clifford, pp.87-125. Fontana Press. New York.

Gieser, Thorsten. 2008. Embodiment, Emotion and Empathy: A Phenomenological Approach to Apprenticeship Learning. Anthropological Theory 8(3): 299-318

Hann, Chris and Hermann Goltz. 2010. Eastern Christians in Anthropological Perspective. Berkeley: University of California Press.

Harding, Susan. 1987. Convicted by the Holy Spirit: the Rhetoric of Fundamental Baptist Conversion. American Ethnologist 14(1):167-181.

Keane, Webb. 2014. Rotting Bodies: the Clash of Stances toward Materiality and Its Ethical Affordances. Current Anthropology 55(S10): S312-S321.

Luhrmann, Tanya Marie. 2012. Prayer as Inner Sense Cultivation: An Attentional Learning Theory of Spiritual Experience. ETHOS 40(3): 359-389.

McGuckin, John. 2008. The Orthodox Church. Oxford: Blackwell Publishing.

Mitchell, Jon. 1997. A Moment with Christ: the Importance of Feeling in the Analysis of Belief. Journal Universty Press of the Royal Anthropological Institute 3(1): 79-94.

Norwich, John and Reresby Sitwell. 1966. Mount Athos. New York: Harper and Row.

Rappaport, Roy. 1999. Ritual and Religion in the Making of Humanity. Cambridge: Cambridge

\section{ENDNOTES}

1. Taken from

http://www.johnsanidopoulos.

com/2014/04/the-erotic-story-of-salvation-and-manic.html (accessed 24 June 2016).

2. Mount Athos has a had a continued

Greek Orthodox presence since, legend has it, the Virgin Mary herself was shipwrecked on its shores. Since then Christian practice has evolved from isolated hermits to a mix of small and large monasteries. It currently is home to nearly 1,000 monks and an equal number of laborers. (Della Dora 2011: 63, Norwhich et al 1966: 19; UNESCO),

3. A visitor from Russia, Seraphim has been at Marouda for two years, staying with the hope of becoming a novice monk to Elder Makarios.

4. An excerpt from the Morning Prayers read before liturgy, translated from Greek.

5. "As long as Moses held up his hands, the Israelites were winning, but whenever he lowered his hands, the Amalekites were winning" (New international Bible, http:// biblehub.com/exodus/17-11.htm. Accessed 24 June 2016.) 
Sophrony, Archimandrite. 1977 His Life is Mine. Crestwood, New York: St. Vladmir's Seminary Press.

60 Minutes. 2011. Mt. Athos The Holy Mountain. CBS. http://www.cbsnews.com/news/mt-athos-a-visitto-the-holy-mountain/

UNESCO. 2009. Mount Athos- UNESCO. http://whc.unesco.org/en/list/454

This work is

licensed under a Creative

Commons At-

tribution-Non-

Commercial

NoDerivs 4.0

International

License. 